\title{
Unraveling the Role of Plastic Waste Pollution in the Amvrakikos Wetlands National Park, Greece: The Stakeholders' Views
}

\author{
Veronika Andrea ${ }^{1}\left(\mathbb{D}\right.$, Paraskevi Mpeza ${ }^{2}$, Dimitris Barelos ${ }^{1,3}$ and Chrysostomos Stylios ${ }^{1, *} \mathbb{C}$ \\ 1 Knowledge and Intelligent Computing Laboratory, Department of Informatics and Telecommunications, \\ School of Informatics and Telecommunications, University of Ioannina, 47150 Arta, Greece; \\ vandrea@kic.uoi.gr (V.A.); dbarelos@cc.uoi.gr (D.B.) \\ 2 Department of Agriculture, School of Agriculture, University of Ioannina, 47100 Arta, Greece; \\ bmpeza@uoi.gr \\ 3 Amvrakikos gulf-Lefkada Management Agency, 47150 Arta, Greece \\ * Correspondence: stylios@uoi.gr; Tel.: +30-26810-50330
}

Received: 20 June 2020; Accepted: 17 July 2020; Published: 22 July 2020

\begin{abstract}
Plastic waste pollution in marine environments is considered a major environmental problem in coastal areas. Relative environmental problems are also recorded in protected wetlands. The National Park of Amvrakikos Wetlands, one of the largest wetlands of Greece, is studied in order to evaluate the influence of plastic waste in the protected area and its surroundings, according to the stakeholders' views. The survey applied using the method of census addressing the key stakeholders in the area of interest and the use of a questionnaire; the data analyzed with the Statistical Package SSPS. The main findings reveal that waste management is not considered satisfactory in the broader area. Marine litter, pollution, overfishing, ecosystem degradation, agriculture and livestock activities, as well as the insufficiency of the municipal solid waste management and recycling system are listed as the most important environmental problems of the coastal area. The stakeholders' participation is regarded as crucial for effective decision making. Therefore, special strategies should be designed involving Information and Communication Technology (ICT) to widely address the local communities and increase their awareness on the problem in order to reduce plastic waste pollution. It should be noted that environmental conditions are closely affiliated with the citizens' quality of life.
\end{abstract}

Keywords: national park; plastic waste; recycling; wetlands; marine ecosystem; microplastics; stakeholders' views

\section{Introduction}

The intensive use of plastic material in every aspect of life has generated a plastic waste stream and the so-called "plastic pollution crisis." The shrinking landfill capacity and the dispersion of plastic debris in the environment further increase this crisis [1,2]. In 2018, global plastics manufacture reached almost 360 million tons with plastics production in Europe at 62 million tons. Post-consumer plastic waste generation across the European Union (EC) reached 29.1 million tons in order to be treated. In 2018, from the post-consumer collected plastic, $25 \%$ of waste was sent to landfills, $32 \%$ to recycling, and $43 \%$ to energy recovery. However, there is a non-collected fraction of plastics, which is not included in the treatment methods [3].

Commonly used plastics are not biodegradable, so they accumulate, rather than decompose, in landfills or in the natural environment. Within their value chain from useful products to becoming waste, plastics show different behavior and performance, so the collected plastic waste does not necessarily reflect the plastic usage on an annual basis [3]. 
Plastic waste which does not go to landfills for disposal has been found in all the compartments of the environment, threatening several ecosystems. Most plastic debris may be transported far away from their source and an estimated amount of 4 to 12 million metric tons (Mt) of plastic waste generated on land have ended up into the marine environment [4]. It should be noted that a lot of research has been performed for the distribution of plastics in the ocean, lakes, and rivers, while littleis known for the fate of microplastics in terrestrial ecosystems. Further research is needed to elucidate the transport mechanisms between land-generated plastics and the open sea.

Entanglement is one of the main consequences of plastic dispersion and can lead to death of marine organisms. Microplastics, which are particles smaller than $5 \mathrm{~mm}$, are small enough to be consumed by bivalves, macro-invertebrates, seabirds, and even fish, earthworms, and insects [5-8]. Microplastics contamination has also an impact on health in aquatic and terrestrial plants [8]. Humans are affected by microplastics, via multiple sources such as edible animal food, inhalation of plastic dust, and to a lesser extent from oral drugs. Chemical additives released from plastic items such as phthalate and bisphenol A (BPA) are present in human population. Although the mechanism of toxicity of chemicals released from plastic in the human body is not precisely known, it seems to be correlated with endocrine disruption [9-12].

Key industries such as tourism and aquaculture fisheries are heavily influenced by plastic pollution. Coastal communities lose income derived from these activities. Cleanup activities, damage to fishing equipment, and removal of plastic debris from propellers and nets induce direct loss in economic value. Impact on biodiversity, aggravation of climate change through uncontrolled incineration as a disposal practice for plastic waste, depletion of natural resources, and invasion of alien species are some consequences considered as indirect loss [13-15].

Ideas including circular economy, material reuse, recycling alternatives, incentives to industry for biodegradable package design, orientation of industry, policy and consumer patterns are behaviors towards the protection of the environment and the need to describe local or national policy [16].

This paper aims to provide information on plastic waste stream in coastal zones of Amvrakikos Gulf and Lefkada, Greece, mainly focusing on the socioeconomic context and wetland values and the connection of management scenarios with resource efficiency. It also recorded different plastic waste streams related to local society, their recycling potential, and innovative management strategies. The main objective of this article is to investigate how the local stakeholders face the issue of plastic waste pollution and its connection with policies and activities.

\subsection{Plastic Waste Characterization in Coastal Zones of Amvrakikos Gulf and the Island of Lefkada, Greece}

Despite the national enforcement of an environmental fee aiming at the reduction of plastic bags, the adoption of extended producer responsibility schemes for more industries, and local industry efforts to follow sustainable methods, the leakage of plastic waste remains a critical problem in the battle against plastic pollution. Rural activities such as agriculture, aquaculture, fishing, and construction generate plastic waste in the field, which may escape from the established procedures for its collection and proper treatment. Local release pathways must be described, and local waste management plans must be tailored to socioeconomic and environmental parameters. For this purpose, monitoring on the beaches and small islands in the Gulf, or shorelines across the wetlands was held to address the current situation, zones of accumulation, and source apportionment of plastic debris. The period of monitoring was from October until December 2019.

The northern part of Amvrakikos Gulf, Greece, is the site formed by the delta of the Louros and Arachthos Rivers, where a mosaic of habitats synthesizes a unique landscape. Artificial land as arable land, perennial crops, orchards and groves, grassland, coastal lagoons, salt marshes, and dunes are encountered. It is a protected ecosystem, both by national legislation and international conventions, namely it a National Park and Ramsar Wetland respectively. Amvrakikos coastal community's economy is heavily dependent on agriculture, aquaculture, and fisheries. A secondary sector in the area constitutes of processing units, of agricultural livestock, fisheries, and several local products of 
unique quality are produced for national and international markets. The tertiary sector in the area mainly includes the retail, trade, tourism, and services. Enterprises in the area are either medium or small local inter-municipal [17].

Wetlands as a land between terrestrial and open water ecosystems have proven to play a key role in trapping marine liter, including large items $[7,18]$. Rivers are an important pathway for plastic transport. High flow takes away large items towards the coast while during low flow, plastic waste is stranded on riverbanks. During high flow, thinner plastic bags are many times trapped from the overhanging vegetation at the bank of the rivers. Furthermore, plastic items on the river route are obstructed at dams.

As the river Arachthos flows through the city of Arta, household items that are concentrated near the banks often are taken away by the river especially during heavy precipitation and strong wind events (Figure 1).

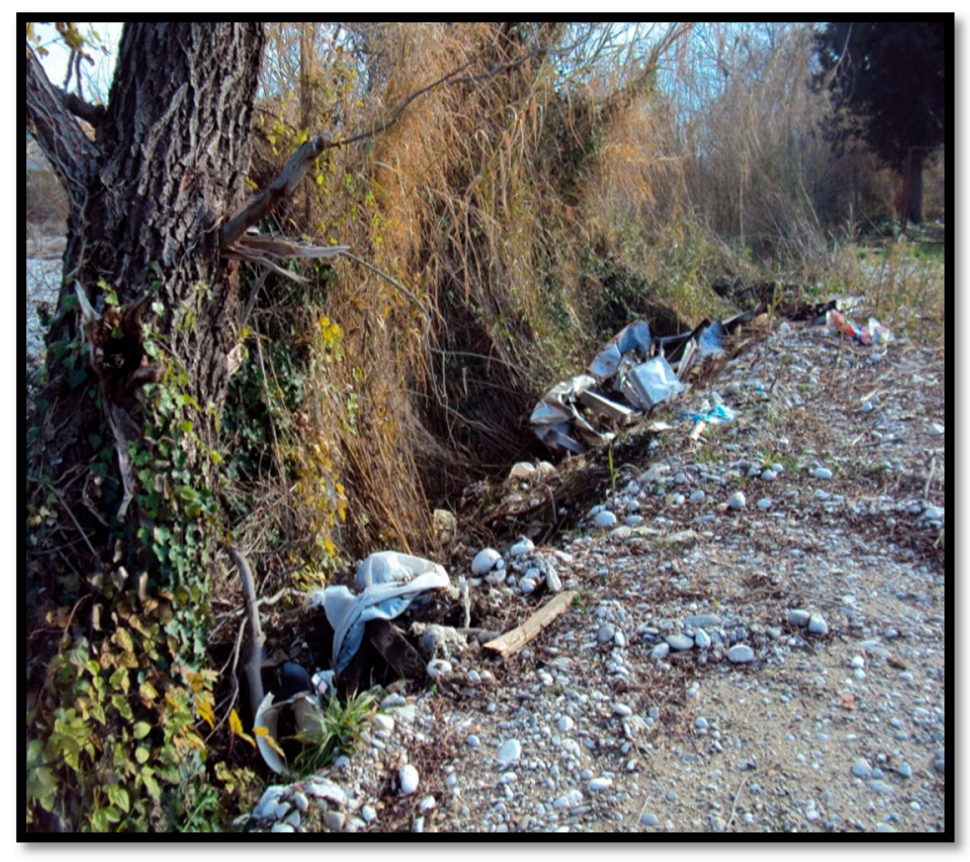

Figure 1. Illegal dumping site at riverside of Arachthos, near the city of Arta (Authors took the photo March 2020).

An essential question is about the source of the discarded plastic items. It seems that they are coming from an old landfill site near the river and a turning point for transshipment of recycled materials. Recycled materials are exposed until their collection and this poses risk for their leakage on the river. Fertilizer sacks and empty agrochemical containers are monitored in proximity with cultivation area. Discarded plastic shotgun ammunition shells are an unwelcome feature in the wetland area. Solid waste distribution in the area was either scattered or concentrated at high densities in illegal dumping sites at riverbanks and the coast [19]. It should be noted that a lot of research has been performed for the distribution of plastics in the sea, lakes and river, while, little is known for the load of plastics and the generated secondary microplastics in the wetlands.

\subsection{Agriculture Sector}

Plastic production that is used in the agriculture sector represents almost $4 \%$ of the total plastic products that are consumed in Europe and the USA [3]. Agriculture plastics include greenhouse covering and tunnel films and nets, irrigation pipes and drippers, containers, bags, olive nets, agrochemical containers, and fertilizer sacks. Thus, in the literature often the term "plasticulture" is used to describe plastic material in agriculture. The studying area has become one of the leading 
regions of Greece in greenhouse cultivation and agriculture films are mainly used in protected cultivars as greenhouses, low tunnel, and mulching [20]. Most of the agricultural plastics are polyolefins, mainly linear low-density polyethylene (LLDPE). In several applications, they may also contain ethylene-vinyl-acetate (EVA) or ethylene-butyl-acrylate (EBA) copolymers. Irrigation pipes are usually made from, HDPE (high-density polyethylene) and/or PVC (polyvinyl chloride). Fertilizers are usually contained in sacks made from LDPE, HDPE, or PP(polypropylene). Plastic containers of HDPE with an internal coating of polyamide (PA) are used for the packaging of liquid agrochemicals [21].

The lifetime duration of agricultural plastic films varies from some months (mulching films) to 3-4 years (greenhouse films), while nets can last 5-10 years and rigid sheets more than 10 years [22]. Plastic wastes are generated during the whole year, but the period of collection of each different material depends on the seasonal production of the crops. Agrochemical containers are another part of the identified plastic waste in the field, which carry pesticide contamination residuals. This plastic material needs to be decontaminated before being incorporated into a material recycling stream. Plastic films exhibit a progressive degradation of their mechanical and spectro-radiometric quality mainly due to their exposition to solar radiation, pesticides, extreme temperatures, high relative humidity, strong wind, and rainfall events, and installation mode [23,24].

Deterioration of plastic films continues after their useful lifetime and it is dependent on the mode of disposal. Degradation occurs indifferent ways, which are happen successive or simultaneously. Fragmentation is the first stage of degradation and occurs by physical forces. Chemical degradation occurs through hydrolysis or oxidation and chemical reactions with agrochemicals. Biodegradation comes next and addresses the enzymatic action of microorganisms on substrates polymers. The variation of the ecosystem's characteristics attribute different mechanisms by which degradation can take place. Polyethylene agriculture films are not listed as biodegradable polymers. Polyethylene material is hydrophobic with extremely resistant bonds. According to recent research, burying mulching films in the soil leaves material with no signs for biodegradation for a long period of time and poses risks to soil fertility [25]. The microplastics load is taken away with runoff precipitation and wind or may adhere to rocks or leach to the groundwater. Quantification of microplastic particles generation on the field is a difficult task [8]. Moreover, the kinetics of their transport as terrestrial systems may operate as a sink for small particles for time scale.

Uniformity of agriculture plastic waste (APW) makes an ideal material for anon-conventional management scenario such as recycling or energy recovery. PE film with pre-oxidants is degraded in small pieces and is not converted to the recycling stream. Mulching films have serious loss of their mechanical properties and are not easily recyclable. Recycling is a challenge for non-point source materials. The rural nature of farmers' activities increases the energy intensive models in waste transportation and collection. Instead of the APW, if correctly collected and treated, it could be used as a secondary raw material (SRF/RDF). An application for the utilization of secondary raw materials is their use as energy sources such as fuel in cement kilns. The consequences of the disposal of APW in fields and landfills pose risks for aesthetic pollution and agronomic landscape degradation, threats to domestic and wild animals, blocking of water flow through drainage ditches, soil fertility undermining, and water pollution impact $[19,26,27]$. Challenges for sustainable APW management are focused on reducing plastic waste by agriculture activities, with the adoption of biodegradable material, and responsible use of APW through recycling and energy recovery processes. Special policies targeted to local farmers must be introduced [28-31].

\subsection{Fisheries and Aquaculture Sector}

Amvrakikos Gulf is a rich fishing ground which encompasses numerous lagoons and coastal fjords, making it an ideal habitat for aquatic organisms. It is characterized by a strong fishing tradition from the ancient times. This tradition continues to today and it confirms the strong linkage of local people with the wetland. Aquaculture and fisheries play an important role in the local economy. 
Most professionals in the fishery sector use lines for their activities, or cages or nets suspended from buoyant structures, or fishing gears floats, nets, ropes, dredges, dredges, traps, and lures. The fishing activity encompasses plastic materials that are used in boat construction, including painting, antifouling coats, and boat maintenance. Once fish are caught, plastic fish boxes and industrial packing crates are used on vessels for the conservation and transportation of fish [32]. Ropes for mooring are made of HDPE, nylon, PE and PET (polyethylene terephthalate) and PVC as tubes in clam aquaculture. Nets and floats are made from a range of plastics, including PP, PE, PVC, PS (polystyrene), and PA, and the applied fishing method or aquaculture system is critical for the fate of plastic material after its lifetime on the environment $[33,34]$. Plastic exposed to sunlight receives mechanical tension from waves and chemical effect of salinity. Furthermore, plastic waste is weathered, and leaching monomers liberate secondary microplastic particles that are suspended in sea water and may be mistaken as a food by aquatic organisms. Furthermore, a serious threat for marine ecosystems seems to be the tendency of lost gear that is accidentally or illegally discarded at sea. Additionally, this equipment is usually washed onto the coastline (Figure 2).

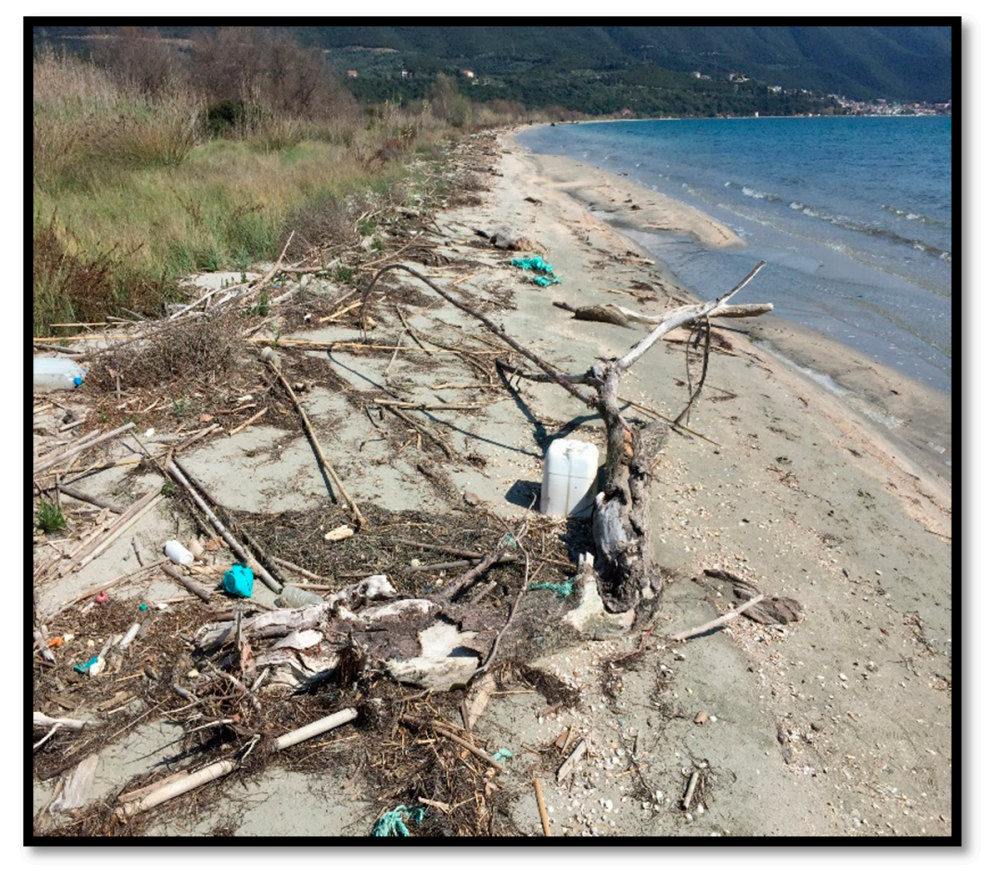

Figure 2. Plastic litter related with fishing activities washed at the side of Agrilos Lagoon (Source: the authors).

Most of the fishing vessels in Amvrakikos Gulf are docked in nature reserves. There are various small ports in the area that constitute localized points, where the most remarkable quantities of plastic debris related to fishing activity, are generated. Plastic items as a tracker of aquaculture activities such as buoys, nets and ropes, are washed onto the coast. In addition, a large quantity of ropes is abandoned in the area. Mismanaged plastic waste such as plastic gloves, single-use plastic bags, food packaging, plastic bottles, cigarette filters, and rubber tires are also accumulated in small fishing ports in the wetlands of Amvrakikos. Microplastic such as plastic fragments, fibers, and foams have been monitored [19]. Large items are easily identified by visual inspection. For small items, which are scattered in the area, source identification was more difficult. This is due to the loss of identifying features, indicative of a long-term environmental exposure. The plastic waste accumulation, which exists in the land area of fishing ports, is a backlash of a long term "littering culture" and highlights capacity constraints of local waste collection systems. More interestingly, in tiny islands in the center of Amvrakikos Gulf, cameras revealed plastic items related to fishing activities had washed ashore. 
It is a fact that marine litter is a universal problem, meaning special strategies are required to reduce aquatic, semi-aquatic, and terrestrial plastic pollution. These strategies should be based on the prevention of plastic waste disposal in marine environments, design of proper management plans with the engagement of key stakeholders, education for recycling and circular economy, abolition of single-use products, research for biodegradable materials, and the adoption of extended producer responsibility schemes. Wetlands constitute significant ecosystems serving as valuable assets for the preservation of the natural environment, resulting in a plethora of beneficial functions for the society such as local growth via sustainable tourism $[35,36]$. To this end, their efficient management should be listed as a top priority.

\section{Materials and Methods}

\subsection{Study Area}

The study area includes six Greek municipalities located in the surroundings of Amvrakikos Wetlands National Park (AWNP) and Lefkada's Marine Protected Areas (LMPA). Namely, the Municipality of Arta, the Municipality of Nikolaos Skoufas, the Municipality of Preveza, the Municipality of Lefkada, the Municipality of Aktio-Vonitsa, and the Municipality of Amphilochia (Figure 3). These municipalities administratively belong to Region of Epirus (Municipality of Arta, the Municipality of Nikolaos Skoufas, the Municipality of Preveza), Region of Ionian Islands (Municipality of Lefkada), and Region Western Greece (Municipality of Aktio-Vonitsa, Municipality of Amphilochia).

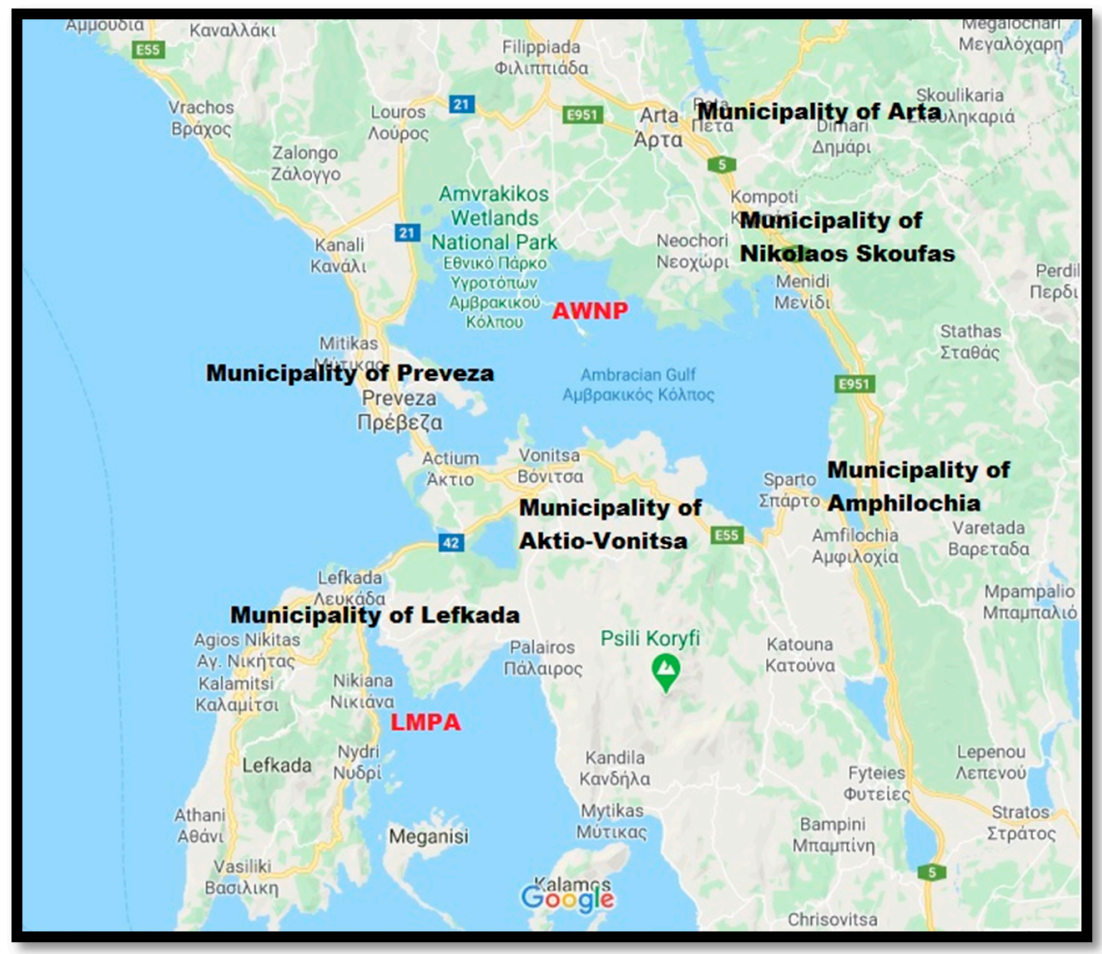

Figure 3. Study Area and the Amvrakikos Wetlands National Park (Source: Google Maps).

The AWNP consists of a complex network of lagoons listing it as the largest wetland area in Greece. The park supports a diverse ecosystem that hosts over 296 different species of birds, 75 of which are considered endangered, several of these live year-round within the marshes of the gulf, the majority spend their winters here or come to mate and raise their offspring [37]. The AWNP is a protected area of both national and international interest [35], while it is protected by the Ramsar Convention. Moreover, the responsibility area of the AWNP includes four sites of the Natura 2000 
Network (GR2110001, GR2110004, GR2310006 and GR2310014), while the LMPA has two sites of interest (GR2220003 and GR2240001). Due to several human activities, there are serious environmental problems. Intensive agriculture, animal husbandry, poaching, and illegal fishing are some of the national park's most important environmental issues.

\subsection{The Survey}

Data were collected during 2019 with the use of personal interviews, which is regarded as the most effective method in sampling research [38]. For the data collection, face-to-face interviews were organized which included close-ended questions and Likert-scale questions. The questionnaire involved a significant range of topics in order to investigate the stakeholders' views regarding their quality of life and environmental protection in the area as well as the existing environmental problems. Moreover, also examined were the stakeholders' views concerning the problem of marine litter, the management of the natural environment regarding the responsible authority in order to implement protection measures, and their awareness on environmental issues including the sources they derive information. Finally, the last section included the demographic characteristics of the respondents. All the questions used in the survey are provided in Supplementary Materials.

In order to collect the data, the participation of the experts and key stakeholders on sustainable waste management issues in the coastal area was vital. Therefore, the first stage of the survey included the screening of the population. For this procedure, all the data for the stakeholders' identification were requested and retrieved officially by the Management Agency of Amvrakikos Wetlands National Park and Lefkada Wetlands. In particular, the Management Agency is the organization responsible for the stakeholders' engagement within a framework of "shared governance," the so-called "co-management of the protected area with the local communities". To this end, it was arranged that the population participating in the survey were the most appropriate ones in order to fulfill the aim of the study. Thus, in order to facilitate the data collection procedure, the identified stakeholders were examined as units. This means that in the screening procedure, there were selected organizations, agencies, and various potential participants of individuals and legal entities. Therefore, 48 units were identified including the municipalities and the respective regional authorities involved in the area of interest, such as aquaculture units, fishermen associations, environmental centers, development agencies, and higher education research institutes. A percentage of about $50 \%$ of the identified units participated in the survey. In particular, 23 questionnaires were collected while the procedure was characterized by low levels of refusal in responding (approximately below 5\%). According to Barelos [39], in the broader area of Amvrakikos, the regional economy is mainly based on the primary (41\%) and tertiary sector (40\%) while almost one in five of the locals is occupied on the secondary sector. To this end the allocation of the questionnaires retrieved by the interviewed are considered as representative for the study area. The survey also included field data collection by videos and photographs for the inspection and evaluation of plastic waste allocation in the coastline and beaches of AWNP and LMPA. With the use of a drone, the authors and a trained operator of the University of Ioannina, accompanied by staff of the management Agency of AWNP and LMPA have organized several autopsies that took part within 8 hours in total flight of the drone. The survey took place before the introduction of the pandemic virus SARS-CoV-2 (COVID-19) in Greece, from October to December 2019 and the statistical package SPSS used for the data processing.

\section{Results}

\subsection{The AWNP and LMPAStakeholders' Profile}

The stakeholders' demographic characteristics were examined and according to the findings (Table 1) most of the respondents (73.9\%) were male, older than 50 years old $(60.9 \%)$, married $(87 \%)$ with two children $(52.2 \%)$, high school $(26.1 \%)$ and university graduates $(26.1 \%)$, and civil servants $(52.1 \%)$ that reside in the Municipality of Preveza (26.1\%). 
Table 1. The stakeholders' demographic characteristics.

\begin{tabular}{|c|c|c|c|c|}
\hline Gender & Male $73.9 \%$ & Female $26.1 \%$ & & \\
\hline Age & $\begin{array}{c}18<(0 \%) \\
18-30(0 \%)\end{array}$ & $31-40(0 \%)$ & $41-50(39.1 \%)$ & $>50(60.9 \%)$ \\
\hline $\begin{array}{l}\text { Marital } \\
\text { Status }\end{array}$ & $\begin{array}{l}\text { Unmarried } \\
\quad 4.3 \%\end{array}$ & $\begin{array}{l}\text { Married } \\
87 \%\end{array}$ & \multicolumn{2}{|c|}{$\begin{array}{l}\text { Divorced or widowed } \\
4.3 \%\end{array}$} \\
\hline $\begin{array}{c}\text { Childhood } \\
\text { without children } \\
21.7 \%\end{array}$ & $\begin{array}{c}\text { One child } \\
4.3 \%\end{array}$ & $\begin{array}{l}\text { Two children } \\
\quad 52.2 \%\end{array}$ & $\begin{array}{c}\text { Three children } \\
13 \%\end{array}$ & $\begin{array}{l}\text { More than three } \\
\quad 4.3 \%\end{array}$ \\
\hline \multirow[t]{2}{*}{$\begin{array}{l}\text { Educational } \\
\text { Level }\end{array}$} & $\begin{array}{c}\text { Primary school } \\
8.7 \%\end{array}$ & $\begin{array}{c}\text { Secondary school } \\
4.3 \%\end{array}$ & $\begin{array}{l}\text { High school } \\
26.1 \%\end{array}$ & \\
\hline & $\begin{array}{l}\text { Technical educational institute } \\
8.7 \%\end{array}$ & $\begin{array}{l}\text { University } \\
26.1 \%\end{array}$ & $\begin{array}{l}\text { Master } \\
21.7 \%\end{array}$ & $\begin{array}{l}\mathrm{PhD} \\
4.3 \%\end{array}$ \\
\hline \multirow[t]{4}{*}{ Profession } & $\begin{array}{c}\text { Private servant } \\
13.1 \%\end{array}$ & $\begin{array}{l}\text { Civil servant } \\
\quad 52.1 \%\end{array}$ & $\begin{array}{c}\text { Freelancer } \\
0.0 \%\end{array}$ & $\begin{array}{c}\text { Farmer } \\
0.0 \%\end{array}$ \\
\hline & $\begin{array}{l}\text { Stock breeder } \\
0.0 \%\end{array}$ & $\begin{array}{l}\text { Aquaculture } \\
4.4 \%\end{array}$ & $\begin{array}{c}\text { Free fisherman } \\
8.7 \%\end{array}$ & $\begin{array}{c}\text { Lagoon cooperative } \\
17.3 \%\end{array}$ \\
\hline & $\begin{array}{c}\text { Provider of tourism-related } \\
\text { services } \\
4.4 \%\end{array}$ & $\begin{array}{l}\text { Other } \\
0.0 \%\end{array}$ & $\begin{array}{l}\text { Pensioner } \\
0.0 \%\end{array}$ & $\begin{array}{l}\text { Housekeeper } \\
\quad 0.0 \%\end{array}$ \\
\hline & $\begin{array}{c}\text { Student } \\
0.0 \%\end{array}$ & $\begin{array}{c}\text { Unemployed } \\
0.0 \%\end{array}$ & & \\
\hline \multirow[t]{3}{*}{ Permanent residence } & $\begin{array}{l}\text { Municipality of Lefkada } \\
8.7 \% \\
\end{array}$ & $\begin{array}{c}\text { Municipality of Arta } \\
17.4 \%\end{array}$ & \multicolumn{2}{|c|}{$\begin{array}{l}\text { Municipality of Nikolaos Skoufas } \\
13 \%\end{array}$} \\
\hline & $\begin{array}{c}\text { Municipality of Preveza } \\
26.1 \%\end{array}$ & $\begin{array}{c}\text { Rest of Epirus } \\
13 \%\end{array}$ & \multicolumn{2}{|l|}{$\begin{array}{c}\text { Municipality of } \\
\text { Amphilochia } \\
13 \%\end{array}$} \\
\hline & $\begin{array}{c}\text { Municipality of Aktio-Vonitsa } \\
4.3 \%\end{array}$ & $\begin{array}{c}\text { Rest of Western Greece } \\
4.3 \%\end{array}$ & & \\
\hline
\end{tabular}

\subsection{The Quality of Life in the AWNP and LMPA}

The stakeholders were asked about the provided quality of life and the existing situation in terms of environmental protection in the area of interest. Therefore, they provided their opinion about the quality of life in the broader area of Amvrakikos surroundings. Almost half of the stakeholders stated that they were satisfied with the quality of life $(47.8 \%)$, while $21.7 \%$ are not at all to less satisfied with their quality of life in the area of interest (Table 2).

Table 2. Frequencies and percentages of the satisfaction with the quality of life according to the stakeholders' views.

\begin{tabular}{ccc}
\hline Level of Satisfaction & Frequency & Percent \\
\hline Absolutely satisfied & 1 & 4.3 \\
\hline Very satisfied & 6 & 26.1 \\
\hline Satisfied & 11 & 47.8 \\
\hline Less satisfied & 4 & 17.4 \\
\hline Not at all satisfied & 1 & 4.3 \\
\hline Total & 23 & 100.0 \\
\hline
\end{tabular}

The stakeholders were also asked to express their satisfaction with the environmental protection status in the coasts of their area. It was observed that $43.5 \%$ were satisfied with the environmental protection status while almost half of them $(47.8 \%)$ were less to not all satisfied with the existing environmental protection status (Table 3). According to Andrea et al. [40], there are several cases worldwide of inadequate protection measures in protected areas that led to serious environmental problems such as deforestation, illegal hunting, forest fires, and pollution. 
Table 3. Frequencies and percentages of the environmental protection status in the coasts according to the stakeholders' views.

\begin{tabular}{ccc}
\hline Level of Satisfaction & Frequency & Percent \\
\hline Very satisfied & 2 & 8.7 \\
\hline Satisfied & 10 & 43.5 \\
\hline Less satisfied & 8 & 34.8 \\
\hline Not at all satisfied & 3 & 13.0 \\
\hline Total & 23 & 100.0 \\
\hline
\end{tabular}

The income satisfaction of respondents was then investigated. It was noticed that more than half were satisfied (34.8\%) and very satisfied (21.7\%) with their income, while $39.1 \%$ were not at all to less satisfied (Table 4). Gateway communities of protected areas adopt a certain attitude towards protection and consequently to the existence of the protected area which is closely affiliated with their dependence on the natural resources. Therefore, they hold a rather negative opinion if their economic activities are reduced due to the restrictions related with the implementation of the protection status. Recent research concludes that the existence of protected areas apart from the environmental scheme has also important impacts the socioeconomic status for the gateway communities [41]. Furthermore, the existing natural assets as well as the development of primary infrastructures for the facilitation of ecotourism growth are critical factors for improving of the residents' quality of life [42].

Table 4. Frequencies and percentages of the stakeholders' satisfaction with their income.

\begin{tabular}{ccc}
\hline Level of Satisfaction & Frequency & Percent \\
\hline No answer & 1 & 4.3 \\
\hline Very satisfied & 5 & 21.7 \\
\hline Satisfied & 8 & 34.8 \\
\hline Less satisfied & 6 & 26.1 \\
\hline Not at all satisfied & 3 & 13.0 \\
\hline Total & 23 & 100.0 \\
\hline
\end{tabular}

\subsection{Environmental Problems in the AWNP and LMPA}

The stakeholders were asked to evaluate the main environmental issues in the natural environment of the coasts of the broader area. The environmental issues addressed are marine litter, pollution from sea accidents and sea traffic, the problem of overfishing and ecosystem degradation, pollution from agriculture and livestock activities, as well as the influence of fishing activities such as dumping of fishing equipment at sea and from aquaculture, the inadequacy of the urban sewage treatment system, the insufficiency of the municipal solid waste management and recycling system, and the pollution resulting from tourist activity and the density of visitors. They were also asked to assess the pollution related with transportation of plastics from a landfill or any other source that causes environmental problems at the coast. A major problem is recognized overfishing and ecosystem degradation, as almost $56.5 \%$ believe that is a very important to important local problem. Other significant problems that follow are the insufficiency of municipal solid waste management and recycling system $(30.4 \%$ very important, $17.4 \%$ important), pollution related toagriculture and livestock activities (34.8\% very important, $4.3 \%$ important) and pollution resulting from the transportation of plastics from a landfill ( $30.4 \%$ very important, $4.3 \%$ important). Another problem also closely affiliated with waste, this time with water waste, was indicated as being the inadequate treatment of urban sewage, as approximately $30.4 \%$ regard it as a very important and important environmental problem. A less important problem was pollution from sea accidents and sea traffic accidents according to the stakeholders' opinion. Additionally, 
the contribution of fishing activity is considered as safe by the respondents. Indeed, pollution from fishing or aquaculture activities receives the lowest rankings (pollution from fishing activities not to less important $39.1 \%$, pollution related with aquaculture activities not to less important $47.8 \%$ ).

Then, the problem of marine litter was separately investigated with a focus on its basic pollutant, plastic waste. The respondents were asked to evaluate the problem of plastic waste atthe coasts of their area. Almost four out of ten noted that problem of plastic waste is a very important problem $(8.7 \%)$ or an important problem (34.8\%) (Table 5).

Table 5. Frequencies and percentages of the stakeholders' evaluation on the problem of plastic waste in the coasts of their area.

\begin{tabular}{ccc}
\hline Importance Level & Frequency & Percent \\
\hline No answer & 1 & 4.3 \\
\hline Not important & 2 & 8.7 \\
\hline Slightly important & 2 & 8.7 \\
\hline Neutral & 8 & 34.8 \\
\hline Important & 8 & 34.8 \\
\hline Very important & 2 & 8.7 \\
\hline Total & 23 & 100.0 \\
\hline
\end{tabular}

In what follows, the stakeholders were asked to provide more specific information on the plastic waste they find in the coastal environment of their area in terms of plastics distribution in place, physical conditions of the plastic material/product, and primary locations that this material/product is usually found. Concerning the usual distribution of plastic waste in the coastal environment, most of the respondents share the opinion that the major accumulation of plastic waste is observed along the coastal roads $(60.9 \%)$ (Figure 4$)$. This could be related with the unsocial behavior of citizens disposing waste on the street, enhancing the phenomenon of road littering [43].

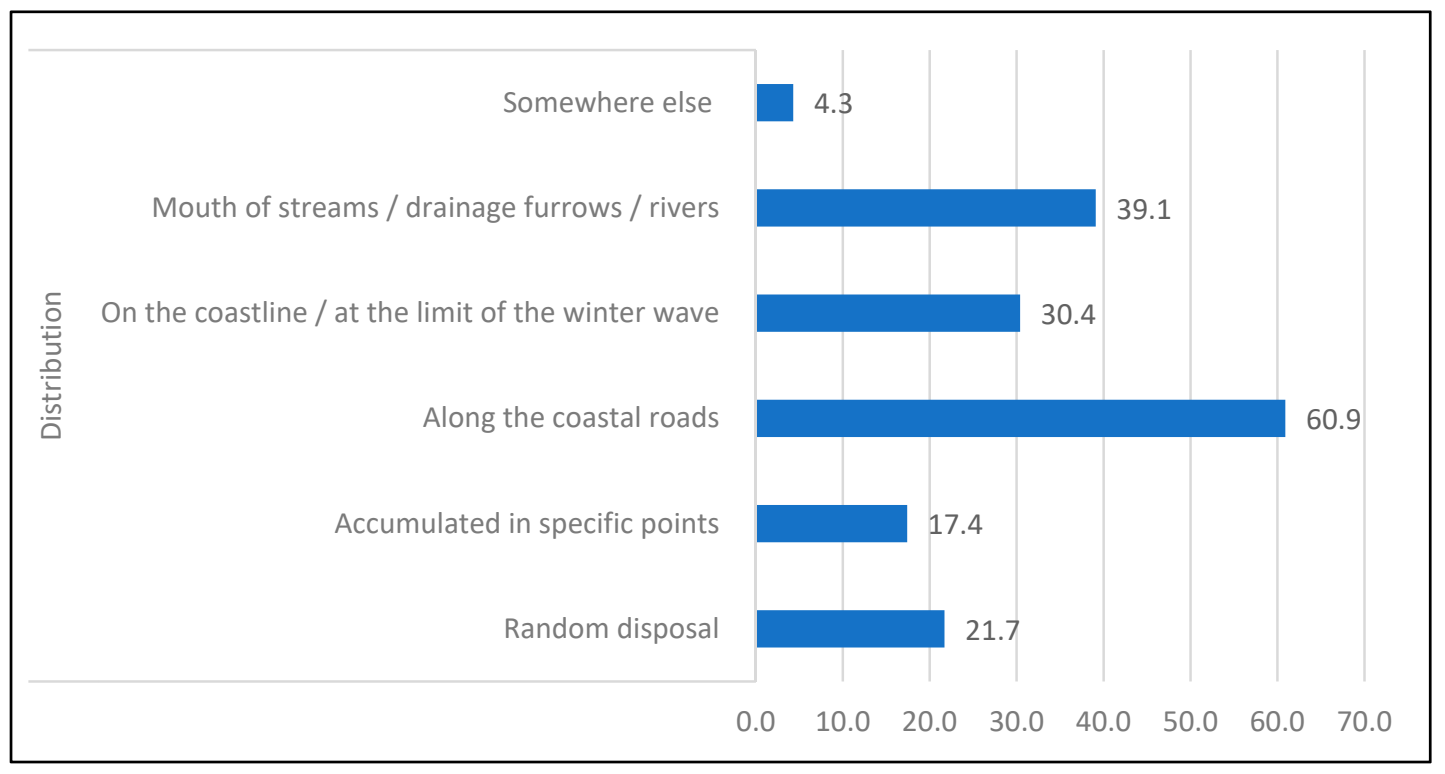

Figure 4. The stakeholders' evaluation on the problem of plastic waste in the coasts of their area.

Furthermore, in regards to the condition that plastic waste was found around the coastal environment in their area, $73.9 \%$ of the respondents answered that it was in its original formation, fully recognizable as material or product; while $56.5 \%$ claimed that it was found in smaller pieces but it 
was possible for them to recognize the plastic waste original formation. Plastic waste is claimed to be usually found in the marine environment as floating particles on the sea $(82.6 \%)$; while almost three out of ten of the questioned stated to have found plastic waste in fishing equipment within the marine environment in their area.

Moreover, it was regarded as very useful to record the stakeholders' views on the important categories of plastic waste that are closely affiliated with environmental problems in the marine environment, namely microplastics and single-use plastics. In regard to the existence of microplastics, more than half of respondents $(56.5 \%$ ) claim to have noticed microplastics in the coasts of their area yet $39.1 \%$ have not noticed any microplastics. More specifically, the stakeholders that claimed to have noticed microplastics in the coast of their area, were also asked on the existence of microplastics in certain locations. To this end, more than half of the respondents $(56.5 \%)$ said that they have noticed the existence of microplastics but insist that these were noticed as particles over floating on the sea. $8.7 \%$ of the respondents that reported to have seen the microplastics in the coastal area of interest also noticed microplastics in fishing equipment.

\subsection{Raising Awareness Issues}

The alarming problem of microplastic in aquatic environments has raised a lot of attention over the last decade in the international research community. Due to this new threat accompanying plastic waste pollution in marine environments, the awareness of AWNP and LMPA stakeholders was investigated. The survey was focused on the possible impacts on microplastics on human health, on fish and marine mammals, and on the animals whose habitats are on the inland, while the questioned were given the option to report something else, or claim that they are not aware. The majority of the respondents considered $(78.3 \%$ ) claimed that microplastics cause problems in human health as well as on fish and marine mammals. Some $17 \%$ believe that inland animals are impacted by the existence of microplastics too.

Respectively, in regard to the single use plastics that are expected to be banned very soon in Europe (1st January 2021), they were asked to describe in what level they agreed with the ban of the single use plastics. Significantly, the vast majority $(91.3 \%)$ agreed and strongly agreed that the single use plastics should be banned; which is evident with the aim of Figure 5.

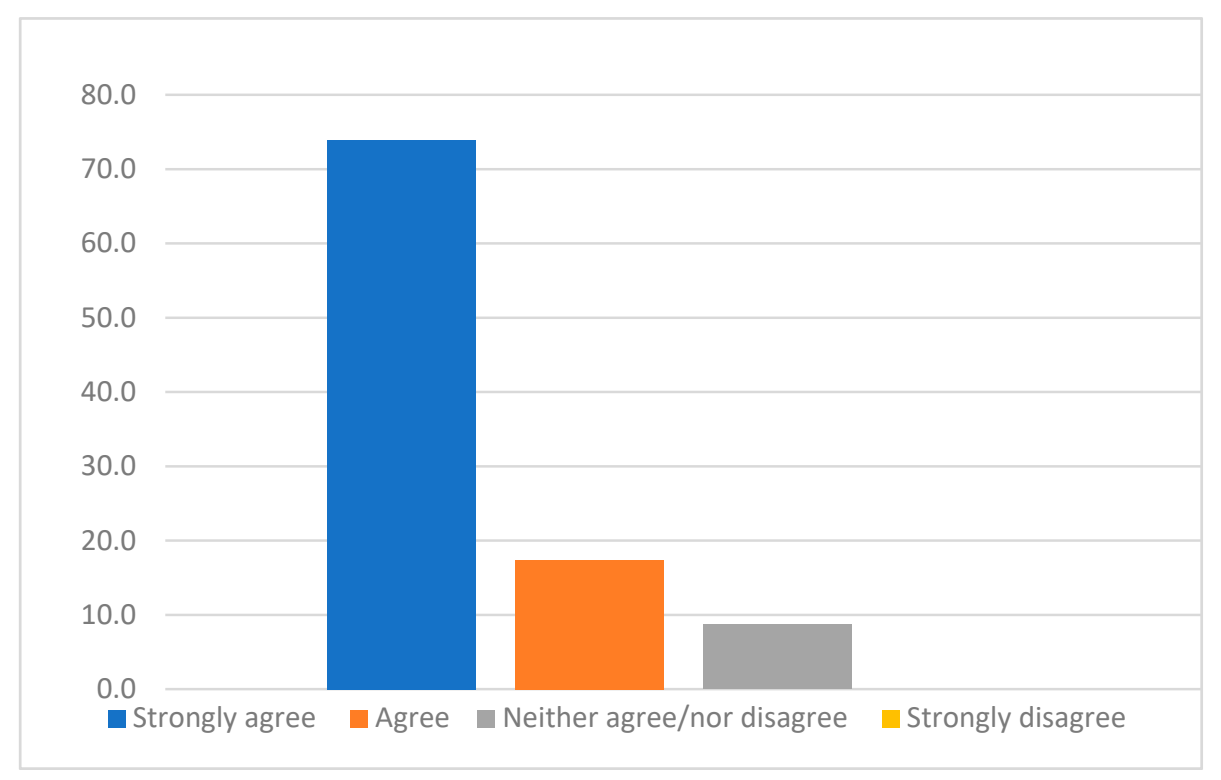

Figure 5. The stakeholders' agreement level on the ban of single use plastics.

In order to investigate the awareness needs of the stakeholders, they were asked who should be responsible for the efficient environmental management in the coasts of their area; and which sources of 
information they prefer in order to be informed about the coast environmental issues. The stakeholders were asked to evaluate the specific body responsibility by the use of 1-10 ranking scale where "1" showed less responsibility and " 10 " the most; while they could attribute the same rank to more than one option. Figure 6 reveals the "10 value ranking" of the most responsible bodies to manage the coastal area according to the stakeholders' views. It is obvious the most popular bodies are the waste management body, the locals themselves, and the local administration. Indeed, in regard to the waste management body, $21.7 \%$ of the respondents stated that is the most important body responsible for the efficient environmental management in the coasts of their area. The local administration is considered by $30.4 \%$ as being the most responsible body for the efficient environmental management; while an important percentage of $34.8 \%$ believes that the locals themselves are responsible to properly manage the coastal area of their residence.

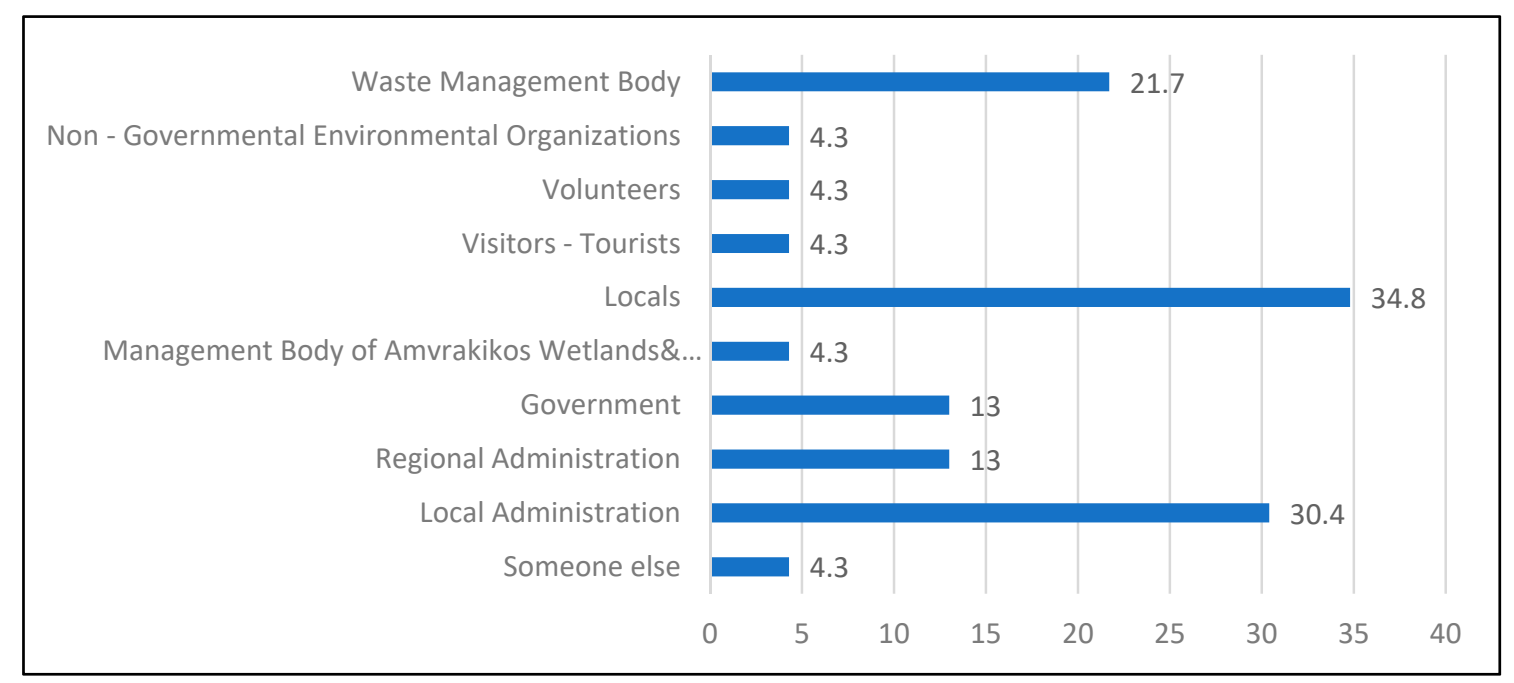

Figure 6. The responsible bodies to manage the coastal area according to the stakeholders' views.

The sources of information that the respondents use to inform themselves about the existing problems of the coasts in their area were then examined. The vast majority (87\%) answered that internet is the main source of information, while the TV and radio are the second most important source with a percentage of $60.9 \%$, with newspapers and magazines $(47.8 \%)$ and social media $(39.1 \%)$ following. About three out of ten mention information from sources such as family and friends and the local administration. It should be noted that education holds a small percentage of $8.7 \%$.

\section{Discussion}

In line with the aim of the study to evaluate the key stakeholders' views on the problem of plastic waste in the surroundings of the AWNP and LMAP and suggest practical measures to reduce environmental pollution, important findings have arisen by this case study. Sustainable coastal management is one of the major goals of the European Blue Strategy. It is of utmost importance to create the proper framework in terms of policy planning and effective implementation of specific measures. In this case study, elaborative baseline research was conducted in order to identify key stakeholders that play a crucial role in decision making and in turn in efficient implementation of strategies, measures, and special activities for the sustainable coastal management of the AWNP and its surroundings.

The level of life quality is an issue of great interest, yet in the case of AWNP it was noticed that the stakeholders, whose residence is located in the northeast part of Greece, were rather satisfied with their quality of life. Majorly, in Lefkada island, tourism growth holds a strong position among the international tourism demand in Greek Islands. The existence of state-of-the-art infrastructures such as the international airport of Aktion in Preveza and also the Ionian and Egnatia highways serve as critical 
advantages for the development of the broader area. More specifically, accessibility is ensured by the airport of Aktion as it provides services on a seasonal basis and connections with various European destinations through several charter flights. The airport has been recently modernized and upgraded and there is a constant increase of passengers' flow [44]. The latter, possibly passthrough Preveza to Lefkada in the touristic season. In addition, there is a continuous road network improvement in this part of Greece. There are already two highways connecting the broader area with all parts of Greece. Egnatia connects the study area with north Greece and the Ionia highway provides accessibility with the capital and the south part of the county. In addition, another important highway, the one of Amvrakia-Aktion is expected to be delivered within the next five years connecting the airport with Preveza, Lefkada with the western part of the country [45].

It is obvious that there is a need to enhance the implementation of the protection status in the broader area of AWNP and LMPA as almost half of the stakeholders are somewhat dissatisfied with the existing situation of the environmental status. There is also a low satisfaction of their incomes. According to Andrea et al. [46] the local people of this area consider that the existence of a unique natural resource, such as the national park and its natural environment, has a major impact on their quality of life. To this end, they opt for the development of sustainable tourism in the broader area serving as an important factor for local economic growth. Therefore, it seems that protection issues are also acknowledged by the stakeholders.

In regard to marine pollution, the European Environmental Agency [47] has indicated human activities as main sources of marine pollution in terrestrial and aquatic ecosystems. The existence of plastics and microplastics in marine environments is an important indicator of their environmental degradation. Therefore, the introduction of monitoring and prediction models on their pathways would provide fundamental information on their location and distribution in marine ecosystems [48]. The main sources of the aquatic ecosystem are proven to be uncontrolled waste disposal at sea, fishing aquaculture, shipping transport tourism, and coastal mining activities. Accordingly, the terrestrial sources are mainly from landfills, tourism deposits on the coast, industries, rivers, flooding benefits, and the insufficiency of the sewage system. The findings of the study point out that some of the most serious environmental problems in the natural environment of the coasts of the national park are closely affiliated with marine litter pollution, overfishing, and ecosystem degradation, agriculture and livestock activities, as well as the insufficiency of the municipal solid waste management and recycling system [49]. To this end, the protection status of the area should be focused on the primary sector including agriculture, livestock farming, and fishing as well as on the tertiary sector including tourism activities mainly arising from mass tourism models in the popular tourism destination of Lefkada. Priority should be also given in the improvement of the public services that the municipalities provide on the waste management framework.

Eventually, it was also proven that efficient planning should be based in stakeholders' participation in decision-making procedures. In fact, there is a need to raise awareness among local groups and provide access in political decisions that affect them. It should take into account that participatory models will support efficient environmental management in the protected area and its surroundings. Locally based administrative authorities are regarded as responsible for the environmental protection and sustainable development in this area. Stakeholders share the view that the waste management bodies should improve their managerial strategies in order to preserve and better protect the AWNP and LMPA from plastic waste pollution. At the same time, personal engagement seems to be acknowledged by the respondents in order to face the problem of marine litter. To this end, special environmental communication programs should be designed by the waste management bodies of the management unit of the national park. It is highly recommended to address the locals in order to enhance their environmental performance on a personal basis. This means raising awareness on plastic waste prevention and recycling.

Moreover, as digital means such the internet, television, and the radio are mostly used to get informed on local sustainable coastal management issues, these tools should be exploited in 
communication and raising awareness programs. Special strategies of circular economy should be implemented in local economies providing examples of success and opportunities for change, not to mention that the creation for stakeholders' networks will facilitate policy measures for alternative waste management. Additionally, the development of a forum is proposed for dialogue with society and the market as well as an electronic platform for the exchange of knowledge and information and for promoting best practices in regard to initiatives preventing waste generation, such as reuse and repair of products and development of corresponding services. Providing information about environmental issues and knowledge of how to act may be the most effective way to influence attitudes and increase environmentally responsible behavior.

It is highly recommended that future research focuses on the locals' views, perceptions, and attitudes towards plastic waste management. In addition, as the deadline for the ban of single-use plastics is approaching, it would be useful to record the locals' views regarding their intention to implement the measure, and also their patterns for replacing a basic category of plastics that is widely used in routine activities of everyday life. It is of utmost importance to shed light in the locals' intentions as the preservation of the AWNP is a major objective for its managers. Along the same line, the research should address tourists, as Lefkada Island is a very popular destination for mass tourism in summer season.

\section{Conclusions}

The establishment of the basic infrastructures that secure accessibility in the area of the AWNP and LMPA, and the existence of the national park itself, have a positive impact for the stakeholders in their perceptions in regard to their quality of life.

Whereas it was evident that the nature of the existing environmental issues requires multilevel cooperation, within the local public services such as the municipalities that are responsible for the waste management systems both for solid and water waste, the management Agency of the Amvrakikos Gulf-Lefkada, agriculture/aquaculture and fishermen's associations. In this effort, it should not be disregarded at all the importance of the local communities' participation in decision making.

The study area constitutes a fragile ecosystem that plays a crucial role for local growth in several municipalities surrounding the Amvrakikos Gulf-Lefkada protected areas. Their economic activities seem to be in high dependence with the coastal zone. Primary production and tourism sector are the main development fields in the broader area. Therefore, proper management of plastic waste in its mainland means that single-use plastics and microplastics will be significantly reduced on the coasts of Amvrakikos and Lefkada.

The introduction of new methodologies towards raising awareness of both locals and tourists for plastic waste reduction and recycling is suggested in this area [50]. More specifically, Web-GIS for monitoring along special ICT applications that are accessible on-line should be designed in order to raise awareness on plastic waste pollution in the AWNP and provide alternatives that could be adopted on a personal basis [51]. Additionally, monitoring the plastics and microplastics pathways could potentially assist the local authorities in detecting the most harmful plastic pollution sources and in turn, in designing the proper measures for dealing with the problem more efficiently.

In regards to fishermen and farmers, special environmental programs should be designed in order to inform them of the threatening problem of marine waste pollution and its consequences on primary production. Yet practical solutions should address activities of their work field that will facilitate them in performing actions in crops of fishing industry that will be characterized by environmental consciousness.

Supplementary Materials: The following are available online at http://www.mdpi.com/2077-1312/8/8/549/s1, The Questionnaire of the survey.

Author Contributions: V.A. conceptualized the research. C.S. and V.A. designed the research and the methods and materials for its implementation. V.A., P.M. and D.B. designed the questionnaire used for the data collection and C.S. supervised the overall progress. D.B. conducted the fieldwork and data collection. V.A. and P.M. conducted 
the data analysis and organized the original draft preparation. C.S. reviewed and edited the submitted manuscript. All authors have read and agreed to the published version of the manuscript.

Funding: This research publication presents results achieved in project No 80390 "Recycling Strategies for the Coastal Sustainable Waste Management towards R\&D Innovation: RE.CO.RD." INTERREG V-A, Cross-border Cooperation Programme Greece-Italy 2014-2020. The project is co-funded by European Union, European Regional development Funds (E.R.D.F.) and by National Funds of Greece and Italy.

Acknowledgments: This publication presents the results achieved in project No 80390 “Recycling Strategies for the Coastal Sustainable Waste Management towards R\&D Innovation: RE.CO.RD" co-funded by European Union, European Regional development Funds (E.R.D.F.) and by National Funds of Greece and Italy.

Conflicts of Interest: The authors declare no conflict of interest.

\section{References}

1. Laville, S. Single-Use Plastics a Serious Climate Change Hazard, Study Warns. Published in the Newspaper The Guardian on 15th May 2019. Available online: https:/www.theguardian.com/environment/2019/may/15/ single-use-plastics-a-serious-climate-change-hazard-study-warns (accessed on 12 June 2020).

2. Andrady, A.L.; Neal, M.A. Applications and societal benefits of plastics. Philos. Trans. R. Soc. B Boil. Sci. 2009, 364, 1977-1984. [CrossRef] [PubMed]

3. Plastics Europe, Association of Plastics Manufacturers (2019) Plastics-The Facts. Available online: https://www.plasticseurope.org/application/files/9715/7129/9584/FINAL_web_version_Plastics_the_ facts.4.2019_14102019.pdf (accessed on 5 June 2020).

4. Geyer, R.; Jambeck, J.R.; Law, K.L. Production, use, and fate of all plastics ever made. Sci. Adv. 2017, 3, e1700782. [CrossRef] [PubMed]

5. Toussaint, B.; Raffael, B.; Angers-Loustau, A.; Gilliland, D.; Kestens, V.; Petrillo, M.; Rio-Echevarria, I.M.; Eede, G.V.D. Review of micro- and nanoplastic contamination in the food chain. Food Addit. Contam. Part A 2019, 36, 639-673. [CrossRef] [PubMed]

6. Gil-Delgado, J.A.; Guijjarro, D.; Cosalvez, R.U.; Lorez-Iborra, G.M.; Ponz, A.; Velasco, A. Presence of plastic particles in waterbirdfaeces collected in Spanish lakes. Environ. Pollut. 2017, 220, 732-736. [CrossRef] [PubMed]

7. Helcoski, R.; Yonkos, L.T.; Sanchez, A.; Baldwin, A. Wetland soil microplastics are negatively related to vegetation cover and stem density. Environ. Pollut. 2020, 256, 113391. [CrossRef]

8. Hurley, R.; Horton, A.; Lusher, A.; Nizzetto, L. Plastic waste in the terrestrial environment. Plast. Waste Recycl. 2020, 163-193. [CrossRef]

9. Meeker, J.D.; Sathyanarayana, S.; Swan, S.H. Phthalates and other additives in plastics: Human exposure and associated health outcomes. Philos. Trans. R. Soc. B Boil. Sci. 2009, 364, 2097-2113. [CrossRef]

10. European Food Safety Authority-EFSA Panel on Contaminants in the Food Chain (CONTAM). Presence of microplastics and nanoplastics in food, with particular focus on seafood. EFSA J. 2016, 14, 4501.

11. Teuten, E.; Saquing, J.; Knappe, D.; Barlaz, M.; Jonsson, S.; Björn, A.; Rowland, S.J.; Thompson, R.C.; Galloway, T.S.; Yamashita, R.; et al. Transport and Release of Chemicals from plastics to the environment and to wild life. Philos. Trans. R. Soc. 2009, 364, 2027-2045. [CrossRef]

12. Wang, F.; Wong, C.S.; Chen, D.; Lu, X.; Wang, F.; Zeng, E.Y. Interaction of toxic chemicals with microplastics: A critical review. Water Res. 2018, 139, 208-219. [CrossRef]

13. Vlachogianni, T. Marine Litter in Mediterranean Coastal and Marine Protected Areas-How Bad Is It. A Snapshot Assessment Report on the Amounts, Composition and Sources of Marine Litter Found on Beaches, Interreg Mediterranean ACT4LITTER \& MIO-ECSDE 2019. Available online: http://mio-ecsde.org/ wp-content/uploads/2019/02/SNAPSHOT-ASSESSMENT-OF-ML-IN-MED-MPAs_final.pdf (accessed on 10 June 2020).

14. Center of International Environmental Law CIEL. Plastic \& Climate. The Hidden Costs of a Plastic Planet. Available online: www.ciel.org/plasticandclimate (accessed on 11 June 2020).

15. Godfrey, L. Waste Plastic, the Challenge Facing Developing Countries-Ban It, Change It, Collect It? Recycling 2019, 4, 3. [CrossRef]

16. Brouwer, R.; Hadzhiyska, D.; Ioakeimidis, C.; Ouderdorp, H. The social costs of marine litter along European coasts. Ocean Coast. Manag. 2017, 138, 38-49. [CrossRef] 
17. European Commission Fish/2006/09. Assessment of the Status, Development and Diversification of Fisheries-Dependent Communities. The Case Study of Amvrakikos. Available online: https://ec.europa.eu/ fisheries/sites/fisheries/files/docs/body/amvrakikos_en.pdf (accessed on 5 June 2020).

18. Liu, H.; Tanga, L.; Liua, Y.; Zenga, G.; Lua, Y.; Wang, J.; Jiangfang Yu, M. Wetland-a hub or microplastic transmission in the global ecosystem. Resour. Conserv. Recycl. 2019, 14, 153-154. [CrossRef]

19. Ieronimaki, M. Tracking of Solid Waste on the Amvrakikos' Coast Line. Assessment of the Transfer of Pollution through the Arachthos River. Master Thesis, University of Thessaly faculty of Health Sciences Veterinary Department, Volos, Greece, 2017.

20. Savvas, D.; Ropokis, A.; Ntatsi, G.; Kittas, C. Current situation of greenhouse vegetable production in Greece. Acta Hortic. 2016, 443-448. [CrossRef]

21. Briassoulis, D.; Babou, E.; Hiskakis, M.; Scarascia, G.; Picuno, P.; Guarde, D.; Dejean, C.; Scarascia-Mugnozza, G. Review, Mapping and analysis of the agricultural plastic waste generation and consolidation in Europe. Waste Manag. Res. 2013, 31, 1262-1278. [CrossRef] [PubMed]

22. Scarascia-Mugnozza, G.; Sica, C.; Giovanni Russo, G. Plastic materials in European agriculture: Actual use and perspectives. J. Agric. Eng. 2011, 3, 15-28. [CrossRef]

23. Briasoullis, D.; Hiskaki, M.; Babou, E.; Antioxos, S.K.; Papadi, C. Experimental investigation of the quality characteristics of agriculture plastic wastes regarding their recycling and energy recover potential. Water Manag. 2012, 32, 1075-1090.

24. Vox, G.; Loisi, R.V.; Blanco, I.; Scarascia-Mugnozza, G.; Schettini, E. Mapping of Agriculture Plastic Waste. Agric. Agric. Sci. Procedia 2016, 8, 583-591. [CrossRef]

25. Kyrikou, I.; Briassoulis, D. Biodegradation of Agricultural Plastic films. A Critical Review. J. Polym. Environ. 2007, 15, 125-150. [CrossRef]

26. Briassoulis, D.; Hiskakis, M.; Scarascia-Mugnozza, G.; Picuno, P.; Delgado, C.; Dejean, C. Labeling scheme for agricultural plastic wastes in Europe. Qual. Assur. Saf. Crop. Foods 2010, 2, 93-104. [CrossRef]

27. Van Emmerik, T.H.M.; Schwarz, A. Plastic debris in rivers. Wiley Interdiscip. Rev. Water 2019, 7, 1398. [CrossRef]

28. Briassoulis, D. An Overview on the Mechanical Behaviour of Biodegradable Agricultural Films. J. Polym. Environ. 2004, 12, 65-81. [CrossRef]

29. Briassoulis, D. Analysis of the mechanical and degradation performances of optimised agricultural biodegradable films. Polym. Degrad. Stab. 2007, 92, 1115-1132. [CrossRef]

30. Hopewell, J.; Dvorak, R.; Kosior, E. Plastics recycling: Challenges and opportunities. Philos. Trans. R. Soc. B Boil. Sci. 2009, 364, 2115-2126. [CrossRef] [PubMed]

31. NOVAMOD Bioplastics and Biobased Products. Available online: https://www.novamont.com/eng/readpress-release/novamont-bioplastics-and-bio-based-products-at-k-2019/ (accessed on 11 March 2020).

32. Food and Agriculture Organization of the United Nations (FAO). Microplastics in Aquaculture and Fisheries. Technical Paper; ISBN 978-92-5-109882-0. Available online: http://www.fao.org/3/a-i7677e.pdf (accessed on 5 June 2020).

33. UNEP. Marine Plastic Debris and Microplastics: Global Lessons and Research to Inspire Action and Guide Policy Change. 2016. Available online: https://wedocs.unep.org/handle/20.500.11822/7720 (accessed on 15 May 2020).

34. Sandra, M.; Devriese, L.; De Raedemaecker, F.; Lonneville, B.; Lukic, I.; Altvater, S.; Compa Ferrer, M.; Deudero, S.; Torres Hansjosten, B.; Alomar Mascaró, C.; et al. Knowledge Wave on Marine Litter from Aquaculture Sources. D2.2 Aqua-Lit project. Oostende, Belgium, 2019. Available online: https://aqua-lit.eu/assets/content/D2.2. $\% 20$ Knowledge $\% 20$ wave $\% 20$ on $\% 20$ marine $\% 20$ litter\%20from $\% 20$ aquaculture $\% 20$ sources_upd.pdf (accessed on 1 June 2020).

35. Tampakis, S.; Tsantopoulos, G.; Andrea, V. Policies for the Management of Protected Areas; Publication of the Department of Forestry and Management of the Environment and Natural Resources; Democritus University of Thrace: Orestiada, Greece, 2014; pp. 62-70.

36. Han, J.H.; Choi, A.S.; Oh, C.-O. The Effects of Environmental Value Orientations and Experience-Use History on the Conservation Value of a National Park. Sustainability 2018, 10, 3372. [CrossRef]

37. Amvrakikos Wetlands National Park; Amvrakikos Management Body: Preveza, Greece, 2008; pp. 1-16. Available online: https://www.amvrakikos.eu/english/foreas.pdf (accessed on 13 May 2020).

38. Kiochos, P.A. Statistics; Interbooks Publishing: Athens, Greece, 1993. 
39. Barelos, D. Determination of Levels of Pesticide Residues in Surface Waters and Sediments in the Wetlands of Arachthos river-Amvrakikos gulf and the lagoons of Rodia-Tsoukalio-Logarou. Master Thesis, University of Ioannina, Ioannina, Greece, September 2006.

40. Andrea, V.; Tampakis, S.; Tsantopoulos, G.; Manolas, E. Environmental problems in protected areas. Manag. Environ. Qual. Int. J. 2014, 25, 723-737. [CrossRef]

41. Järv, H.; Kliimask, J.; Ward, R.D.; Sepp, K. Socioeconomic Impacts of Protection Status on Residents of National Parks. Eur. Countrys. 2016, 8, 67-85. [CrossRef]

42. Tampakis, S.; Andrea, V.; Karanikola, P.; Pailas, I. The Growth of Mountain Tourism in a Traditional Forest Area of Greece. Forests 2019, 10, 1022. [CrossRef]

43. Bateson, M.; Robinson, R.; Abayomi-Cole, T.; Greenlees, J.; O'Connor, A.; Nettle, D. Watching eyes on potential litter can reduce littering: Evidence from two field experiments. PeerJ 2015, 3, e1443. [CrossRef]

44. Civil Aviation Authority. Air Traffic Statistics of the Airport of Aktio. Available online: http://www.ypa.gr/ en/profile/statistics/yearstatistics/ (accessed on 15 May 2020).

45. Karagiannis, N. The Project of the Double Connection of Lefkada with Aktio-Amvrakia Begins. Published in the Newspaper Ypodomes on 20th May 2020. Available online: https://ypodomes.com/xekinaei-to-ergo-tisdiplis-syndesis-leykadas-me-to-aktio-amvrakia/ (accessed on 20 May 2020).

46. Andrea, V.; Tsantopoulos, G.; Tampakis, S.; Arabatzis, G. Involving local people in sustainable rural development and conservation: A response to the economic crisis. Int. J. Green Econ. 2013, 7, 374. [CrossRef]

47. European Environmental Agency. Marine Environmental Pressures. 2018. Available online: https: //www.eea.europa.eu/themes/water/europes-seas-and-coasts/marine-environmental-pressures (accessed on 18 February 2020).

48. Stocchino, A.; De Leo, F.; Besio, G. Sea Waves Transport of Inertial Micro-Plastics: Mathematical Model and Applications. J. Mar. Sci. Eng. 2019, 7, 467. [CrossRef]

49. TEN ECOPORT. Sustainable Development of Sea-Corridors and Coastal Waters: The TEN ECOPORT Project in South East Europe; Stylios, C., Floqi, T., Marinski, J., Damiani, L., Eds.; Springer International Publishing: Basel, Switzerland, 2015; ISBN 978-3-319-11384-5.

50. Kolios, S.; Vorobev, A.V.; Vorobev, A.V.; Stylios, C.D. GIS and Environmental Monitoring; Springer Science Business Media LLC: Basel, Switzerland, 2017; Volume 20.

51. Kolios, S.; Stylios, C.D.; Petunin, A.A. A WebGIS platform to monitor environmental conditions in ports and their surroundings in South Eastern Europe. Environ. Monit. Assess. 2015, 187, 574. [CrossRef] [PubMed]

(C) 2020 by the authors. Licensee MDPI, Basel, Switzerland. This article is an open access article distributed under the terms and conditions of the Creative Commons Attribution (CC BY) license (http://creativecommons.org/licenses/by/4.0/). 